\title{
IMPROVING THE STUDENTS' WRITING SKILL BY USING PROCESS WRITING APPROACH AT THE SECOND GRADE STUDENTS OF SMK GRAFIKA GOWA MAKASSAR
}

\author{
St. Asriati AM., Maharida \\ Fakultas Keguruan dan Ilmu Pendidikan, Universitas Muhammadiyah Makassar \\ e-mail:asrie006@yahoo.com. \\ Fakultas Keguruan dan Ilmu Pendidikan, Universitas Muhammadiyah Makassar \\ e-mail: maharida.manindar@yahoo.com.
}

\begin{abstract}
The research questions of this research were how is the improvement of students' skill in writing descriptive text views from its grammar through writing process approach at the second grade (TKJ Department) of SMK Grafika Pallangga, how is the improvement of students' skill in writing descriptive text views from its organization through writing process approach at the second grade (TKJ Department) students of SMK Grafika Pallangga, and how is the activeness of students in writing descriptive text through writing process approach at the second grade (TKJ Department) students of SMK Grafika Pallangga. The researcher used Classroom Action Research (CAR). The aimed of this research were to find out the improvement of students' writing skill and their activeness in learning process through Writing Process Approach.

Two cycles had been conducted, where each cycle consisted of four meetings. It employed writing test as instrument. A number of subjects of the research were 42 students in the second grade (TKJ Department) conducted of 19 women and 23 men. The researcher took real data from the school to know the students' writing skill. The results of the student's writing test in cycle 1 and cycle 2 had increased in different scores. There was increasing by students at the end action of second cycle. The research findings indicated that use of writing process approach could increase the students' writing skill. The means scores of students in Diagnostic test was 59.84 became 66.38 in cycle 1, and after revision in the cycle 2 the mean score in cycle 2 was 70.79 by implemented of descriptive text. The successful of minimal criteria (KKM) was 65 while cycle 1 , there were 2 (4.76\%) students get poor, 27 (64.29\%) get fair, and 13 (30.95\%) get good meant that students who achieved the successful minimal criteria (KKM) more than a half of them. In cycle 2 there was $25(59.52 \%)$ get fair and $17(40.48 \%)$ get fair.
\end{abstract}

Keywords: Writing approach, students, and descriptive.

Writing is one of the four skills in English that is necessary to be taught. Many students say that writing is the most difficult one. It is caused by their ignorance about what and how to write. Terry (2009:2) argues that the reason most people never write is concerned with mistakes. Graves (1994:59) assumes such mistakes are the result of their little understanding of the pre-requisite knowledge for writing, such as grammar. Writing does not merely mean applying grammatical rules; it is more students' learning to communicate their written forms without worrying in making mistakes. Indeed, they also experience problem in getting ideas, organizing ideas and developing details, choosing correct 
sentences, as well as maintaining paragraph unity. That's why, teacher is demanded to use method that can encourage students.

Process writing approach is designed to lead students to provide of activities to help them in wide array of writing skill necessary for academic writing (Keenan in Zainuddin, 2009:2). It changes the traditional practice, which focuses on the finished work, to a new methodology, in which students are given the experience of going through the process of writing as writers which consists of five interrelated phases: prewriting, writing, revising, editing, and publishing. During the prewriting phase, students choose a topic and generate ideas, often through brainstorming and oral discussion. Once they have chosen and explain their topic, they begin drafting. As they compose their first draft, they are encouraged to let their ideas flow on to the paper without concern for perfection in form or mechanics. After completing the first draft, students reread their papers and, with feedback from the teacher or their peers, get ready to revise. Revisions are aimed at conveying the writer's ideas as effectively as possible. Finally, the paper is edited for correct agreement, use of articles, pluralization, syntactic forms, punctuation, spelling, grammar, and other important aspects of writing in order to be presented for publishing. As result, process writing approach allows students to concentrate on one test at the time and to experience the value of peer feedback in developing their ideas for effective written expression (Paregoy and Boyle, 2005:136).

After thinking over, the researcher then decides to implement the writing process approach to improve the students writing skill in case of descriptive text. It will be held at the second grade students of SMK Grafika Gowa. In that school the researcher has found some problems related to writing skill faced by the students. The students are still lack of interest in learning writing and ability to express their own idea through writing in case of descriptive text. It is proved from their successful minimal criteria $(\mathrm{KKM})$ are 65 while the students just got 59. It means still low. Such problems were found by the researcher through observation and teaching-learning process which has been done when PPL taken place. 


\section{REVIEW OF RELATED LITERATURE}

\section{A. Process Writing Approach}

\section{What is process writing approach?}

Process writing approach is the way in teaching writing and it has been researched in depth over the past several years with both first language learners. Writing process approach is a method in learning English where the students create their ideas and experience on the paper by doing process and they pretend their self as a good writer without worrying about mistakes. Writing is a process, not a product. This means that a piece of writing is always possible to review and revise, and review and revise again.

Process writing approach is a potential method to provide students' phase in learning not only applying grammatical rules but also communicating their ideas in written form (Peregoy and Boyle, 2005:45). This approach views writing learners as creators of texts, and so, they need to experience what writers actually do as they write. Providing the students with phase means give them useful and systematic process in order to be able to communicate their ideas in written form. By being given process, the students will be lifted from a situation in the traditional way of teaching writing for teaching writing by receiving enough feedback to help students develop their ideas in the process of writing. Besides that, they also receive feedback from their fellow classmates. They then use the feedback to revise their writings before they edit and finally submit their final writings.

Graham and Perin, in Rahmat (2003:20) explain the process of writing approach stress activities that emphasize extended opportunities for writing the process approach treats all writing as a creative act which requires time and positive feedback to be done well. In process writing, the teacher moves away from being someone who sets students a writing topic and receive the finished product for correction without any intervention in the writing process itself. 


\section{The Steps of Process Writing Approach}

The process writing approach is one way that teaches students how to write completely. This process involves several steps that culminate in a complete final product. Hale, in Zanuddin (2009:14) assumes it consists of prewriting, writing, revising, editing, and publishing. Each of these steps is important to have a successful writing. When a writer follows these steps they will achieve the goal of an interesting and successful writing. They are as following:

\section{Pre-writing}

The first step of process writing approach is pre-writing. This step includes brainstorming, gathering information, and thinking, planning, and listing. The purpose of brainstorming is to develop a topic. Writers will also develop ideas that support the topic. This time the writers may also choose what audience they intend to address with their writing in order to focus their information on specific points. The purpose of pre-writing is to take a chosen topic and gather thoughts together involving that topic in coherent way.

Graham and Perin in Rahmat (2003:18) explain that pre-writing engages students in activities designed to help them generate or organize ideas for their composition. Engaging the students in such activities before they write a first draft improves their quality of their writing. Prewriting activities include gathering possible information for a paper through reading or developing a visual representation of their ideas before sitting down to write. Brainstorming is prewriting activity in which you come up with a list of ideas about a topic on your own in small groups with your classmates (Oshima, 1997:15).

2. Writing

The second step of process writing approach is writing. The writer begins with their first draft. This draft will be a culmination of all of the research and information pieced together from pre-writing. The writer also included their own ideas and supporting fact within their writing. A writer 
may also use this time to explore others ideas or areas concerning their topic in order to improve the core of their paper. The purpose of composition, therefore, is simply to make ideas into a composition that meets the needs of chosen audience. It is not important that this first draft be perfect. The draft stage is where you really begin writing. The most important thing here is to get word onto paper. It is not the time to worry about spelling, grammar, punctuation, or the best wording (Brown, 1989:18).

\section{Revising}

It is important to tie the type of revision that is possible for each learner to his or her stage of language acquisition. For example, students in the early stages may not yet have developed the skills for describing possessives and tenses; they may only just be learning how to write nouns in the plural form and match them to the correct verb forms (Haynes, 2007:111).

\section{Editing}

Editing involves going back over the writing and making changes to its organization, style, grammatical and lexical correctness, and appropriateness. Like all the other parts of the writing process, editing does not occur in a fixed place in the process. Writers can be periodically reviewing what they write, editing it, and then proceeding with the writing. Thus, editing is not restricted to occurring after all the writing has been completed. Learners can be encouraged to edit through the feedback that they get from their classmates, teacher and other readers. Such feedback is useful if it occurs several times during the writing process and is expressed in ways that the writer finds acceptable and easy to act on (Nation, 2009:120).

5. Publishing

The final step in the writing process is publication. When publishing a work, the author is sharing their writing with others. This could mean small-scale, such as parents, peers, and teachers, or large-scale, such as 
within a book or magazine. Publication is often the driving force behind writing. It compels the writer to do their best throughout every step of the writing process so that they are left with a perfectly polished piece that may be enjoyed by others. The purpose for publishing a work is simply to share a work with others and to promote a sense of satisfaction and accomplishment in the author when they see their work in final form (Hale, 2009:2).

\section{B. Concept of Writing}

\section{Definition of Writing}

Lindbolm in Fatmawaty (2010:13) gives definition of writing as studying to focus our mind on important matters, and learning about them. By this activity, a person can find the solution of difficult problem, master the fact even by writing, a person can also communicate their mind that cannot be done through other ways. We can say that writing is the act of expressing something through the application of language system. So, when we write, there are two problematic areas namely "what to write and how to write it". It is then understandable that language skills are meant as the ability to manipulate the rules of language conventionally, while extra linguistic system or knowledge of the world refers to what the writer knows about the subject to write.

Writing is production of graphic symbols to form word in a sequence of sentence arranged in particular order and link together in certain ways also writing is process of encoding a message to transfer meaning to reader (Byrne 1980:14).

Another statement about writing skill comes from Widdowson in Saleha (2008:15) states that writing is a communicative activity and is carried out in accordance with certain general principal in which underline the use of language in communication.

Richard, (1997:98) states that writing is a way of expressing thought from mind to printing materials. We can state that writing is a kind of activity 
where writer puts all the ideas in her mind to a paper from words to sentences, sentences to paragraph to essay.

Kroma (1988:37) argues that writing is a kind of activity where the writer expresses all the ideas in his mind in the paper (print) from words to sentence, sentence to paragraph and from paragraph to essay.

While Gebhard, in Rahmatia (2010:22) states that writing is a process of creating an idea and express the meaning in written form. Writing is way of communicating a message to reader for purpose. The purpose of writing is to provide information for and persuade a reader.

Based on definition above, the writer can concluded that writing is expression of writer's idea in a written symbol form on paper in order the reader can read it and get the meaning of writer opinion.

\section{The Forms of Writing}

The forms of writing are divided into five divisions' namely narrative, descriptive, recount, expository and argumentative.

\section{Narrative}

Narrative is the form of writing used to relate the story of acts or events. It places occurrences in time and tells what happened according to natural time sequences. Types of narrative include short stories, novels, and new stories, as well as large part of our everyday social interchange in the form of letters and conversation (McDougal, Littlell \& Company, 1999:104).

\section{Descriptive}

Descriptive reproduces the way things look, smell, taste, feel, or sound. It may also evoke moods, such as happiness, loneliness, or fear. It is used to create a visual image of people, places, even of units of time-days, times of day, or seasons. It may be used also to describe more than the outward appearance of people. It may tell about their traits of character or personality.

Good description usually has three important qualities. These have a dominant impression supported by specific details, a clearly recognizable mood, and logical development (Wishon and Burks 1980: 128-129). 


\section{Recount}

Recount is a text which retells events or experience in the past. Its purpose is to retell events. The generic structures of recount are orientationevents-re-orientation. It has a similarity with the generic structures of narrative. The differentiated of recount text with narrative text only is in events. There is no complication in recount.

\section{Expository}

Expository is used in giving information, making explanations, and interpreting meanings. It includes editorials; essay, and informative and instructional material. Used in combination with narrative, exposition supports and illustrates. Used apart from narrative, it stands alone as an essay. Used alone or with narrative, exposition may be developed in a number of ways as follows:

a) Process. Exposition may be used to explain a process that is to tell how something is made or done.

b) Definition. An explanation of what a word or a term means is another kind of exposition. The simplest form is a statement and this applies to dictionary definitions.

c) Analysis. It divides a subject into parts and examines those parts.

d) Criticism. It involves evaluation, which is analyzing and weighing strengths and weaknesses.

\section{Argumentative}

Argumentative is used in persuading and convincing. It is closely related to exposition and it is often found combined with it. The aim is to make a case or to prove or disprove a statement or proposition. It may present arguments to persuade the reader to accept an idea or a point of view.

\section{The Components of Writing}

The good writing skill can be analyzed to group and varied skills. Heaton (1988:135) divides components writing into five main areas. They are grammar, mechanics, vocabulary, content and organization. 


\section{Grammar}

Grammar concerns about the ability to write correct and appropriate sentences. The writer has to give attention for preposition, tenses such as using of verbs, nouns, adjective, also conjunction and articles. Brown (1989:34) states that grammar is a system of rule governing the conventional and relationship of words in sentences.

\section{Mechanics}

It is related with the ability to use correctly words to the written language such as using of capitalization, punctuation, spelling. It is very important to lead the readers to understand or recognize what the written means to express. The use of favorable mechanics in writing will make the readers easy to the group to conveying ideas or message of writing. The explanation as follows: a) capitalization, the use of capitalization can clarify the ideas. If the sentences are not capitalized correctly, ambiguous and misunderstanding will appear. It also helps to differentiate from sentences to others. The words which are capitalized at beginning of: the name of people, organization, first and last word of title. b) Punctuation. Punctuation can help the readers to identify should be taken as a unit of meaning and suggest how the units of it relate to each other. c) Spelling. Using of spelling has three rules; they are suffixes addition, plural formation and the change of certain words.

\section{Content}

The content of writing is about the ability to think creatively and develop thoughts, excluding all irrelevant information. It should be blear to the readers. So, they can understand what the messages convey and gain information from it. Also, the content of writing should be well unity and complete because the characteristic of good writing has unity and completeness.

\section{Vocabulary}

Vocabulary is an essential part of compose writing. The writes need vocabulary mastery well to express or write their ideas. The effective using 
of words or vocabulary in writing must be relevant with the topic to let the readers perceive and feel it. Someone who lack of vocabulary will be difficult to compose what they are going to express but appropriate words will help writers to compose writing.

\section{Organization}

Organization is the ability to develop ideas and topic which relevant in a united form. On the other hand, it concern in ways of writer to arrange and organize the ideas or messages in writing. There are many ways in process of organization writing involves coherence, order of importance, general to specific, specific to general, chronological order and spatial pattern.

\section{6. $\quad$ Language Use}

Coke in Ismayanti (2008:19) states that language us in writing description and other forms of writing involve correct usage and point of grammar. However, considering that there are many points of grammar, the writer would like to quote a little literature about verbs, use modifier or adjective, adverbs, and participles in the writing, a modifier may other be a phrase. A single, well-chosen- modifier is often more effective than several used together. If it is difficult to describe with over used or warn-out modifier, find more interesting synonyms, in the dictionary.

\section{RESEARCH METHOD}

This research used classroom action research (CAR) that consisted of planning, action, observation and reflecting. It conducted in two cycles each cycle comprises four meetings. Cycle one was to observe the students' competence in writing by using process writing approach. After finding the result of cycle one, the researcher continued to the second cycle to improve the prior cycle.

This research was located at the second grade of SMK Grafika Pallangga, Gowa. The researcher chose this location because the researcher sees it was necessary to improve the way in teaching especially to improve the students' writing skill. 
Research subject in this classroom action research was the second grade students of Department of SMK Grafika Pallangga, Gowa Makassar that consisted of 35 students.

In this section, the research used two instruments for collecting data:

1. Observation Sheet

It aimed to collect data about the students' participant in teaching learning process through process writing approach.

2. Test

The test was used to get about the students' writing skill through process writing approach. It was done to know the improvement of writing skill of students. The test was given at the end of cycle one. Then, at the end of cycle two a test is given again as the last evaluation test. From the last test, researcher knew the improvement of students' writing skill.

\section{PROCEDURE OF DATA COLLECTION}

The data was done with the following procedures:

1. The researcher used observation sheet to find out the students' participant in teaching learning process through process writing approach. It was done in every cycle. It was summed at the end of cycle one and two.

2. The researcher gave test to students to find out their improvement of students in writing descriptive text by using process writing approach. The step as follows:

a. Researcher prepared test material or topic for students.

b. Researcher asked students to follow all steps in process writing approach to make writing.

c. Researcher gave correction to their writing based on their mistakes.

There were two components that concerns of the researcher in this research to measure. Those were grammar and organization which used criteria as follows: 


\section{a. Grammar}

\begin{tabular}{|l|c|l|}
\hline Classification & Score & \multicolumn{1}{|c|}{ Criteria } \\
\hline Excellent & $90-100$ & Effective complex construction \\
\hline very good & $80-89$ & Effective but simple construction \\
\hline Good & $70-79$ & $\begin{array}{l}\text { Major problem in simple/ complex } \\
\text { construction }\end{array}$ \\
\hline Fair & $60-69$ & Major problem in simple \\
\hline Poor & $0-59$ & $\begin{array}{l}\text { Virtually no mastery of sentences } \\
\text { construction rules }\end{array}$ \\
\hline
\end{tabular}

Harmer in Husna (2007)

b. Organization

\begin{tabular}{|l|c|l|}
\hline Classification & Score & \multicolumn{1}{|c|}{ Criteria } \\
\hline Excellent & $90-100$ & Fluent expression ideas clearly \\
\hline very good & $80-89$ & $\begin{array}{l}\text { Somewhat copy- loosely organized but } \\
\text { mind ideas stand out }\end{array}$ \\
\hline Good & $70-79$ & Not fluent but ideas stand out \\
\hline Fair & $60-69$ & Not fluent/ ides confused \\
\hline Poor & $0-59$ & Does not communicated, no organization \\
\hline
\end{tabular}

Harmer in Husna (2007)

\section{PROCEDURE OF DATA ANALYSIS}

To find out the mean score of the students' writing test through process writing approach, researcher used the following formula:

$$
\begin{aligned}
& X=\frac{\sum x}{N} \\
& X \quad=\text { Mean Score } \\
& \sum X=\text { The sum of all score } \\
& N \quad=\text { the total number of sample, (Gay, 1981:298). }
\end{aligned}
$$


To calculate percentage students' achievement in grammar and organization researcher used this formula:

$$
\begin{aligned}
& \mathbf{P}=\frac{\boldsymbol{F}}{\boldsymbol{N}} \boldsymbol{x} \mathbf{1 0 0} \\
& \mathrm{P} \quad=\text { Rate percentage } \\
& \mathrm{F} \quad=\text { Number of correct } \\
& \mathrm{N} \quad=\text { Number of sample, ( Sudjana, 1990:83) }
\end{aligned}
$$

To know the improvement of the students' writing skill, the researcher used percentage technique as follows:

$$
P=\frac{X_{2}-X_{1}}{X_{1}} \times 100
$$

Where:

$\mathrm{P} \quad$ : percentage of the students

$\mathrm{X}_{1}$ : the first mean score

$\mathrm{X}_{2}$ : the second mean score, ( Hasan in Arief, 2011)

From the basic standard above the researcher used the standard score for the total value of the students' writing by calculating the standard score given, as follows:

a. Scores 90-100 is classified as excellent.

b. Scores $80-89$ is classified as very good.

c. Scores 70- 79 is classified as good.

d. Scores 60-69 is classified as fair.

e. Scores 0-59 is classified as poor, (Depdikbud in Saleha, 2008: 22)

\section{FINDINGS AND DISCUSSION}

The findings of classroom action research dealing with the answer of the problem statement which aims to improve students' achievement in writing descriptive test. The findings consist of students' achievement in writing and observation result. It's about the students' activeness in teaching and learning process. To measure the students' achievement of their writing result there are two 
components of writing that is concerned by the researcher, namely: grammar and organization.

\section{Grammar}

a. the improvement of students' mean score in writing views from grammar

Table 1. The Students' Mean Score and Improvement in Grammar

\begin{tabular}{|c|c|c|c|c|c|}
\hline \multirow{2}{*}{ Indicators } & \multicolumn{2}{|c|}{ Writing views of Grammar } & \multicolumn{2}{c|}{ Improvement (\%) } \\
\cline { 2 - 6 } & D- Test & Cycle I & Cycle II & D-test to CI & CI to CII \\
\hline Mean score & 59.14 & 64.90 & 70.09 & 9.74 & 7.99 \\
\hline
\end{tabular}

The table above indicates that there is improvement of the students' mean score of grammar from D-Test to cycle I and cycle II, where the result of D-Test students' mean score in grammar is 59.14 after evaluation in cycle I it becomes 64.90 so the improvement from D-Test to cycle I is 9.74 .

The research findings from the table above, indicates that there is improvement of the students' score in grammar from cycle I to cycle II, where in cycle I the improvement of students' score is 9.74. After analyzed the difficulties that the students faced in writing process and repaired the weakness in cycle I then applying writing process approach and then giving them evaluation in the end of cycle II the improvement of the students' mean score is 7.99.

To see clearly the improvement of the students' writing ability views from grammar can be presented as the following chart:

b. The students' Tabulation of Frequency in Writing View from Grammar Based on the data analysis the students' score in writing grammar are got from the result of the test in cycle I and cycle II in the following table and graphic is presented: 
Table 2. The Students' Tabulation of Frequency in Grammar

\begin{tabular}{|c|c|c|c|c|c|}
\hline \multirow[t]{2}{*}{ Classification } & \multirow[t]{2}{*}{ Score } & \multicolumn{2}{|c|}{ Frequency } & \multicolumn{2}{|c|}{ Percentage } \\
\hline & & Cycle I & Cycle II & Cycle I & Cycle II \\
\hline Excellent & $90-100$ & 0 & 0 & $0 \%$ & $0 \%$ \\
\hline Very Good & $80-89$ & 0 & 0 & $0 \%$ & $0 \%$ \\
\hline Good & $70-79$ & 9 & 16 & $21.43 \%$ & $38.10 \%$ \\
\hline Fair & $60-69$ & 30 & 26 & $71.43 \%$ & $61.90 \%$ \\
\hline Poor & $0-59$ & 3 & 0 & $7.14 \%$ & $0 \%$ \\
\hline \multicolumn{2}{|c|}{ Total } & 42 & 42 & $100 \%$ & $100 \%$ \\
\hline
\end{tabular}

\section{Organization}

a. The Improvement Of Students' Mean Score In Writing Views From Organization

Table 3. The Students' Mean Score and Improvement in Organization

\begin{tabular}{|c|c|c|c|c|c|}
\hline \multirow{2}{*}{ Indicators } & \multicolumn{2}{|c|}{ Writing views of Organization } & \multicolumn{2}{c|}{ Improvement (\%) } \\
\cline { 2 - 6 } & D- Test & Cycle I & Cycle II & D-test to CI & CI to CII \\
\hline Mean score & 61.07 & 67.86 & 71.64 & 11.12 & 5.57 \\
\hline
\end{tabular}

The table above indicates that there is improvement of the students' mean score of organization from D-Test to cycle I and cycle II, where the result of D-Test students' mean score in organization is 61.07 after evaluation in cycle I it becomes 67.86 so the improvement from D-Test to cycle I is 11.12 . 
The research findings from the table above, indicates that there is improvement of the students' score in organization from cycle I to cycle II, where in cycle I the improvement of students' score is 11.12. After analyzed the difficulties that the students faced in writing process and repaired the weakness in cycle I then applying writing process approach and then giving them evaluation in the end of cycle II the improvement of the students' mean score is 5.57 .

\section{b. The Students' Tabulation of Frequency in Organization}

Based on the data analysis the students' score in writing organization are got from the result of the test in cycle I and cycle II in the following table and graphic is presented:

Table 4. The Students' Tabulation of Frequency in Organization

\begin{tabular}{|c|c|c|c|c|c|}
\hline \multirow[t]{2}{*}{ Classification } & \multirow[t]{2}{*}{ Score } & \multicolumn{2}{|c|}{ Frequency } & \multicolumn{2}{|c|}{ Percentage } \\
\hline & & Cycle I & Cycle II & Cycle I & Cycle II \\
\hline Excellent & $90-100$ & 0 & 0 & $0 \%$ & $0 \%$ \\
\hline Very Good & $80-89$ & 0 & 3 & $0 \%$ & $7.14 \%$ \\
\hline Good & $70-79$ & 16 & 26 & $38.10 \%$ & $61.90 \%$ \\
\hline Fair & $60-69$ & 26 & 13 & $61.90 \%$ & $30.95 \%$ \\
\hline Poor & $0-59$ & 0 & 0 & $0 \%$ & $0 \%$ \\
\hline \multicolumn{2}{|c|}{ Total } & 42 & 42 & $100 \%$ & $100 \%$ \\
\hline
\end{tabular}

\section{The Result of Writing Skill}

a. The Students' Mean Score In Writing Skill Result 
Table 5. The Students'Mean Score and Improvement in Writing Skill

Result

\begin{tabular}{|c|c|c|c|c|c|}
\hline \multirow{2}{*}{ Indicators } & \multicolumn{3}{|c|}{$\begin{array}{c}\text { The Result of Students' Writing } \\
\text { Skill }\end{array}$} & \multicolumn{2}{c|}{ Improvement (\%) } \\
\cline { 2 - 6 } & D- Test & Cycle I & Cycle II & D-test to CI & CI to CII \\
\hline Mean score & 59.84 & 66.38 & 70.79 & 10.93 & 6.64 \\
\hline
\end{tabular}

The table 5 above shows the mean score and improvement of the students' writing skill result. The result of students' mean score in D-test is 59.84. Then in cycle I is 66.38 and the students' improvement in writing skill result from the D-test to cycle I is 10.93 .

The research findings from the table above, indicates that there is improvement of the students' score in writing result from D-Test to cycle II, where in cycle I the improvement of students' score is 10.93, after implementing Writing Process Approach and giving evaluation in the end of cycle II the improvement of the students' score is 6.64 .

\section{b. The students' Tabulation of Frequency of the Students' Writing Skill Result}

Based on the data analysis the students score in writing result are got from the result of the test in cycle I and cycle II in the following table and graphic is presented: 
Table 6. The Students' Tabulation of the Students' Writing Skill Result

\begin{tabular}{|c|c|c|c|c|c|}
\hline \multirow[t]{2}{*}{ Classification } & \multirow[t]{2}{*}{ Score } & \multicolumn{2}{|c|}{ Frequency } & \multicolumn{2}{|c|}{ Percentage } \\
\hline & & Cycle I & Cycle II & Cycle I & Cycle II \\
\hline Excellent & $90-100$ & 0 & 0 & $0 \%$ & $0 \%$ \\
\hline Very Good & $80-89$ & 0 & 0 & $0 \%$ & $0 \%$ \\
\hline Good & $70-79$ & 13 & 17 & $30.95 \%$ & $40.48 \%$ \\
\hline Fair & $60-69$ & 27 & 25 & $64.29 \%$ & $59.52 \%$ \\
\hline Poor & $0-59$ & 2 & 0 & $4.76 \%$ & $0 \%$ \\
\hline \multicolumn{2}{|c|}{ Total } & 42 & 42 & $100 \%$ & $100 \%$ \\
\hline
\end{tabular}

4. The Improvement of Students' Writing Skill Result from D-Test to Cycle II

The means score of students writing achievement from D-Test to Cycle II can be shown below:

Table 7. The Improvement of Students' Writing Skill from D-Test to Cycle II

\begin{tabular}{|c|c|c|c|c|c|c|}
\hline \multirow{2}{*}{ Indicators } & \multicolumn{3}{|c|}{$\begin{array}{c}\text { The Result of Students' } \\
\text { Writing Skill }\end{array}$} & \multicolumn{3}{c|}{ Improvement (\%) } \\
\cline { 2 - 7 } & D- Test & Cycle I & Cycle II & $\begin{array}{c}\text { D-test to } \\
\text { CI }\end{array}$ & $\begin{array}{c}\text { CI to } \\
\text { CII }\end{array}$ & $\begin{array}{c}\text { D-test to } \\
\text { CII }\end{array}$ \\
\hline $\begin{array}{c}\text { Mean } \\
\text { score }\end{array}$ & 59.84 & 66.38 & 70.20 & 10.93 & 5.75 & 17.31 \\
\hline
\end{tabular}

The table 5 shows the mean score and improvement of the students' writing skill result. The result of students' mean score in D-test is 61.07. Then in cycle I is 66.38 and the students' improvement in writing skill result from the D-test to cycle I is 10.93 .

The research findings from the table above, indicates that there is improvement of the students' score in writing result from D-Test to cycle II, 
where in cycle I the improvement of students' score is 10.93, after implementing Writing Process Approach and giving evaluation in the end of cycle II the improvement of the students' score is 5.75 .

\section{Observation Result}

The following table and graphic show the observation result of the students' activeness in learning writing from cycle I to cycle II.

Table 8. The students' observation result during teaching and learning process

\begin{tabular}{|c|c|c|c|c|}
\hline \multirow[b]{2}{*}{ Cycles } & \multicolumn{4}{|c|}{ Activeness } \\
\hline & $\begin{array}{c}\text { 1 }^{\text {st }} \text { Meeting } \\
(\%)\end{array}$ & $\begin{array}{c}2^{\text {nd }} \text { Meeting } \\
(\%)\end{array}$ & $\begin{array}{c}3^{\text {rd }} \text { Meeting } \\
(\%)\end{array}$ & $\begin{array}{c}4^{\text {th }} \text { Meeting } \\
(\%)\end{array}$ \\
\hline Cycle 1 & 44.64 & 52.98 & 60.12 & 73.81 \\
\hline Cycle 2 & 68.45 & 67.85 & 76.19 & 84.52 \\
\hline
\end{tabular}

\section{CONCLUSION AND SUGGESTION}

This chapter contains conclusion and suggestion based on the research findings in previous chapter, the researcher puts forward the following conclusion and suggestion.

\section{A. CONCLUSION}

Based on the findings above the researcher concludes that:

The use of writing process approach could increase the students' writing skill. It can be shown of the students' mean score in writing from D-Test to cycle I until cycle II. The students mean score of D-Test is 59.84, the mean Score of cycle I is 66.38 and cycle II was 70.79. The students' improvement from D-test to cycle I is $10.93 \%$, cycle I to cycle II is $6.64 \%$ and from D-Test to Cycle II is $18.29 \%$, so there is significant improvement of the students achievement from DTest to cycle II in learning through writing process approach.

This led the conclusion that the application of this approach is needed in English language teaching and learning in increasing their proficiency to create some ideas on their writing. 
The students' activeness in cycle I is $73.81 \%$. After repair the weakness and take action in teaching and learning process through writing process approach, the students' activeness becomes $84.52 \%$ in the last meeting of cycle II. It means that the use of writing process approach is able to improve the students' activeness in learning English especially in teaching descriptive text.

The use of writing process approach could improve the students' ability to know more about their self, and then create it on their writing especially on their descriptive text.

\section{B. SUGGESTION}

Based on the findings above, the researcher suggests that:

1. The English teacher should use writing process approach as one of the alternative ways in teaching writing because it can improve the students writing skill.

2. It is suggested to the English teacher to maximize in giving guidance to the students in learning and teaching process.

3. The students should increase their ability in learning writing with use writing process approach.

\section{BIBLIOGRAPHY}

Brown, Kristine. 1989. Writing Matters. Cambridge: Cambridge University Press. Unpublished.

Fatmawaty. 2010. Increasing the Students' Proficiency through Think-Talk-Write Method. Thesis: UIN Alauddin Makassar.

Gay. L, R. 1981. Education Research: Competencies for Analysis and Applicant, Clurles E. Marril Publishing Company, Colombus.

Graves, Donald. 1994. A Fresh Look at Writing. Portsmouth: Heinemann Educational Book.

Hale, Ali. 2009. Daily Writing Tips: The Writing Process. Education article, (online), Vol. 5, no. 2, (http://www.dailywritingtips.com/the-writingprocess/, retrieved 19 May 2011). Unpublished.

Hardly. 1993. Efficient and Flexible English Writing. New York. Harpen Collin. 
Haynes, Judie. 2007. Teaching English Language Learners. Alexandria: Virginia USA.

Heaton, JB. 1988. Writing English Language Tests. New Edition. New York: Longman publishing.

Jayanti, Retno Dwi. 2010. Teaching Writing Paragraph trough Brain Based Learning Strategy. Thesis. Makassar: Fakultas Keguruan dan Ilmu Pendidikan Universitas Muhammadiyah Makassar.

Kroma. 1988. Action Research in Teaching Composition. Vol 24 forum Washington DC.

McDougal, Little \& Company. 1999. Basic Skill in English. United Stated of America.

Nation, I.S.P. 2009. Teaching ESL/EFL Reading and Writing. New York and London.

Paregoy, Susanne F, and Boyle, Owen F. 2005. Reading Writing and Learning in ESL. USA: Pearson Educational, Inc. Unpublished.

Rahmat. 2003. Improving the English Writing Ability of the Third Year Student of MAN Kajuara Bone through Diary Writing. Thesis: UIN Alauddin Makassar.

Richard, J. 1997. Approach and Method in Language Teaching. London: Cambridge University Press. Unpublished.

Rahmatia. 2010. Using Dictation Technique to Improve Students' Writing Ability Thesis: UIN Alauddin Makassar.

Saleha. 2008. Icreasing the students' Writing Skill through Think-Talk-Write Method. Thesis. Makassar: Fakultas Keguruan dan Ilmu Pendidikan Universitas Muhammadiyah Makassar.

Wishon, George and Burks. 1980. Let's write English. New York: Litton Education Publishing, Inc.

Zainuddin, Akram. 2009. Improving Writing Skill through Writing Process Approach. Thesis: Universitas Negeri Makassar. 